ISSN 1392-3196 / e-ISSN 2335-8947

Zemdirbyste-Agriculture, vol. 101, No. 4 (2014), p. 373-380

DOI 10.13080/z-a.2014.101.047

\title{
Spring barley as affected by nitrogen and sulphur fertiliser rates calculated using different diagnostic methods
}

\author{
Gediminas STAUGAITIS ${ }^{1}$, Zita BRAZIENE ${ }^{2}$, Antanas MARCINKEVIČIUS ${ }^{2}$, \\ Romas MAŽEIKA ${ }^{1}$, Šarūnas ANTANAITIS ${ }^{1}$, Rūta STAUGAITIENE ${ }^{1}$ \\ ${ }^{1}$ Agrochemical Research Laboratory, Lithuanian Research Centre for Agriculture and Forestry \\ Savanorių 287, Kaunas, Lithuania \\ E-mail: agrolab@agrolab.lt \\ ${ }^{2}$ Rumokai Experimental Station, Lithuanian Research Centre for Agriculture and Forestry \\ Rumokai, Vilkaviškis distr., Lithuania
}

\begin{abstract}
Assessing the response of spring barley (Hordeum vulgare L.) to the nitrogen and sulphur fertiliser rates calculated using different diagnostic methods was the main aim of the experiment conducted at the Rumokai Experimental Station of the Lithuanian Research Centre for Agriculture and Forestry in 2010-2012. The experiment was carried out on a Bathihypogleyi-Calc(ar)ic Luvisol (LVk-gld-w) with a predominant soil texture of silt loam on heavy clay. The mineral sulphur content determined in $0-60 \mathrm{~cm}$ soil layer in spring was very low in 2010 and 2012 and medium in 2011; the treatment of spring barley crop with $\mathrm{S}_{15-20}$ rates the grain yield increased by $5.1-23 \%$, straw yield - by $8.3-19.4 \%$. Mineral nitrogen levels in 0-60 cm soil layer were high and very high $\left(102-173 \mathrm{~kg} \mathrm{ha}^{-1}\right)$ at the end of spring barley tillering stage (BBCH 28); at the same time the content of total nitrogen in barley leaves was optimal. Due to this, the adjustment of supplementary fertilisation (increasing/decreasing of the nitrogen rate by $20-60 \mathrm{~kg}$ $\mathrm{ha}^{-1}$ ) had no significant effect on the crop yield, productivity components and starch and crude protein content in grains. Foliar fertilisation of spring barley increased the grain yield statistically significantly only in 2010 when mineral sulphur and mineral nitrogen content in $0-60 \mathrm{~cm}$ soil layer at the spring barley tillering stage (BBCH 28) was significantly lower ( 8.5 and $123 \mathrm{~kg} \mathrm{ha}^{-1}$, respectively) in comparison to the other experimental years. The yield increase was $41.8 \%$ when ammonium sulphate had been applied and $12.1 \%$ when urea had been applied.
\end{abstract}

Key words: foliar testing, Hordeum vulgare, nitrogen and sulphur fertilisers, soil testing.

\section{Introduction}

The yield and grain quality of spring barley are strongly dependent on the correct determination of the optimal nitrogen fertiliser rate. The diagnostic methods used for determining nitrogen content, fertiliser application techniques as well as combining of nitrogen and sulphur fertilisation play a major role in achieving the desired correctness (Zhao et al., 2006; Skwierawska et al., 2008). It is recommended to determine the amount of plant-available nitrogen in soil (in the majority of Northern and Central European countries mineral nitrogen amount available in soil is considered to be readily available to plants) before sowing; nitrogen fertiliser rates should be adjusted based on the agrochemical soil test results (Staugaitis et al., 2009; Wiesler, Armbruster, 2009). Supplementary fertilisation is usually applied at tillering stage; in order to calculate the supplementary rates of nitrogen and/or sulphur fertiliser correctly, it is recommended to firstly determine the content of nitrogen and sulphur in plant leaves (Breuer et al., 2003). A ratio of nitrogen to sulphur is important: the optimal N:S ratio for wheat is 14-17 (Zhao et al., 1996), a similar optimal ratio is recommended for barley as well, yet it may vary substantially depending on the location, climatic conditions, nitrogen and sulphur fertilisation rates (Kanal et al., 2003; Kulhanek et al., 2014).
Several researchers (Blake-Kalff et al., 2000; Aulakh, Malhi, 2004; Zhao et al., 2006; Järvan et al., 2008 ) indicate a positive effect of sulphur fertilisation on cereal crop production; the positive response of cereal crops to sulphur fertilisation was caused by the fact that the initial levels of plant-available sulphur in soil were low (Olfs et al., 2012). Many European countries are facing a problem of low plant available sulphur levels in soil due to the decreasing use of superphosphate and sulphate fertilisers (Zhao et al., 2003; Messick et al., 2005; Shnug, Haneklaus, 2005). Insufficient levels of plant available sulphur in soil block the positive effect of nitrogen fertilisation - yield is not increasing, and the excessive amount of nitrogen which was not consumed by plants becomes an environmental pollutant (Jamal et al., 2010). Plant-available sulphur in soil is mainly in sulphate form; sulphates are readily leached from the soil, especially when higher rates of sulphur fertiliser are applied (Ercoli et al., 2012); therefore the results of determination of labile sulphur amounts vary substantially, even when 0-60 cm soil layer is tested (Ergebnisse..., 2005), and a correlation between the sulphur content in plant leaves and crop yield and the plant-available sulphur amount in soil is not always obtained (Schnug, Haneklaus, 1998). Due to the aforementioned problems the VDLUFA 
standard method (Schwefelversorgung..., 2000) used for determination of plant-available sulphur in soil does not always give reliable results. Major part of the total sulphur in soil is in organic forms (just like total nitrogen and carbon) and is not readily accessible for plants (Jamal et al., 2010). Different researchers have calculated and suggested that an average coefficient of correlation between the total sulphur and total carbon in soil is 0.75 and between the total sulphur and total nitrogen in soil it is 0.65 (Kanal et al., 2003). The data obtained from the research conducted in Western Lithuania suggest that the content of total sulphur in Western Lithuanian soils ranges from $0.006 \%$ to $0.016 \%$, and $\mathrm{N}$ :S ratio ranges from 10 to 15 (Šlepetienè et al., 2007). Sulphur mineralisation and release from the soil organic matter and plant residues is a slow process; it depends on soil type, weather conditions and cultivated crop (Blum et al., 2013).

It is still hard to decide which diagnostic methods are most suitable for the determination of nitrogen and sulphur content in soil. In addition to this, the issue of optimal nitrogen and sulphur fertilisation scheme and rates for barley has yet to be fully solved. The possible approach to solving this problem depends on the chosen frame of reference, which could be quite different: amounts of nitrogen and sulphur required for achievement of the desirable yield; soil mineral nitrogen and mineral sulphur levels in spring and - possibly - at a certain point of the growing period; nitrogen and sulphur content in plant leaves; nitrogen and sulphur content in soil and in plant leaves. The data obtained previously from the experiments conducted in Lithuania suggest that foliar fertilisation of barley crop with nitrogen at the $\mathrm{BBCH}$ 28-31 stage increased the crop productivity by more than $5 \%$, thus the taken action was profitable enough; foliar fertilisation with sulphur did not reach the desired level of profitability (Staugaitis, Pečkyte, 2008). The effect of spring barley crop foliar fertilisation with sulphur is not clarified yet, but this method was quite effective when applied on winter wheat (Kulczycki, 2011).

The aim of our research was to assess the response of spring barley to the nitrogen and sulphur fertiliser rates calculated using different diagnostic methods.

\section{Materials and methods}

The field experiment was conducted at the Rumokai Experimental Station of the Lithuanian Research Centre for Agriculture and Forestry in 2010 2012. The following experimental design was used: 1) spring barley (Hordeum vulgare L.) fertilised with $\mathrm{N}$, $\mathrm{P}_{2} \mathrm{O}_{5}, \mathrm{~K}_{2} \mathrm{O}$ rates calculated for achieving the $5 \mathrm{tha}^{-1}$ grain yield (treatment No. 1), 2) spring barley fertilised with $\mathrm{N}$, $\mathrm{P}_{2} \mathrm{O}_{5}, \mathrm{~K}_{2} \mathrm{O}$ rates calculated for a target $5 \mathrm{t} \mathrm{ha}^{-1}$ grain yield and adjusted according to the results of regular soil tests conducted in spring (treatment No. 2), 3) treatment No. $2+$ sulphur fertiliser rate adjusted to the mineral sulphur $\left(\mathrm{S}_{\min }\right)$ content in 0-60 cm soil layer determined in spring (treatment No. 3), 4) treatment No. 2 + supplementary nitrogen fertiliser rate adjusted according to the results of analyses of nitrogen content in plant leaves at the tillering (BBCH 28) stage (treatment No. 4), 5) treatment No. $2+$ foliar sulphur (ammonium sulphate) fertiliser rate adjusted according to the results of analyses of sulphur content in plant leaves at the tillering (BBCH 28) stage (treatment No. 5), 6) treatment No. 2 + foliar urea fertiliser rate adjusted according to the results of analyses of sulphur content in plant leaves at the tillering $(\mathrm{BBCH}$ 28) stage (treatment No. 6); this treatment was included in order to make it possible to assess the effect of sulphur in treatment No. 5 .

The calculated amounts of phosphorus and

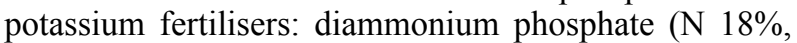
$\mathrm{P}_{2} \mathrm{O}_{5} 46 \%$ ) and potassium chloride $\left(\mathrm{K}_{2} \mathrm{O} 60 \%\right.$ ), and approximately two-thirds of the calculated nitrogen fertiliser - ammonium nitrate ( $\mathrm{N} 34.4 \%$ ), amount were applied to the soil before sowing. The remaining amount of nitrogen fertiliser was applied to the soil of all experimental plots at the end of spring barley tillering stage (BBCH 29-30), i.e. 4-10 June (in the experimental plots of treatment No. 3 ammonium nitrate was replaced with ammonium sulphate: N 20\%, S 24\%).

On 10-16 June (BBCH 39-42), foliar fertilisation was carried out: plants in the plots of treatment No. 5 were treated with ammonium sulphate at $15 \mathrm{~kg} \mathrm{ha}^{-1}$ rate, and plants in the plots of treatment No. 6 - with urea at $6.9 \mathrm{~kg} \mathrm{ha}^{-1}$ rate. Rates of fertiliser active ingredients applied are presented in Table 1.

The results of analysis of the three-year averages revealed that spring barley plants, treated with the fertiliser rates adjusted according to the results of regular soil tests conducted in spring (treatments Nos. 2-6), took up the fertiliser nitrogen amount by $6.5 \%$ more when compared to the plants treated with the rate calculated for achieving the $5 \mathrm{t} \mathrm{ha}^{-1}$ grain yield (treatment No. 1). The uptake of fertiliser phosphorus and potassium by plants was respectively only $15 \%$ (phosphorus) and $74 \%$ (potassium) of the applied rates calculated for achieving the $5 \mathrm{t} \mathrm{ha}^{-1}$ grain yield.

The spring barley cultivar 'Beatrix' was preceded by sugar beet. Total size of the experimental plot was $36 \mathrm{~m}^{2}(12 \times 3 \mathrm{~m})$, harvested area $-22 \mathrm{~m}^{2}(10 \times$ $2.2 \mathrm{~m}$ ). Four replications of each treatment were used; the randomised block experimental design was applied. In spring, soil samples were collected within 15-20 April, pre-sowing fertilisation and sowing (4.5 million viable seeds per hectare) of barley were conducted within 2327 April, harvesting of crop was carried out on 7 (2010), 17 (2011) and 13 (2012) August.

Soil samples for determination of $\mathrm{pH}$, plant availablephosphorus and potassium contentwere collected from $0-20 \mathrm{~cm}$ soil layer of every replication within $15-20$ April. At the same time soil samples were collected from $0-30$ and $30-60 \mathrm{~cm}$ soil layers for determination of the mineral nitrogen and mineral sulphur content. During the growing season at spring barley tillering stage $(\mathrm{BBCH}$ 28) the soil samples for determination of the mineral nitrogen and mineral sulphur content were collected from the experimental plots of two replications of treatments No. 2 and 3.

Chlorophyll meter SPAD-502 ("Minolta", Japan) was used for the determination of chlorophyll index (in the blue $400-500 \mathrm{~nm}$ and red 600-700 nm wavelength regions) in the leaves of spring barley plants from the experimental plots of two replications of every treatment at barley tillering $(\mathrm{BBCH} 28)$ and at the end of barley heading (BBCH 55) stages. At the same time the above-ground plant parts were collected from the experimental plots of all four replications of treatments Nos. 2-6 for determination of the total nitrogen and total sulphur content. The samples collected from the same 
Table 1. Rates of fertiliser active ingredients applied to spring barley crop

\begin{tabular}{|c|c|c|c|c|c|c|c|c|}
\hline \multirow{3}{*}{$\begin{array}{c}\text { Treatment } \\
\text { No. }\end{array}$} & \multirow{3}{*}{ Year } & \multicolumn{7}{|c|}{ Fertilisation rate $\mathrm{kg} \mathrm{ha}^{-1}$ of fertiliser active ingredients } \\
\hline & & \multicolumn{2}{|c|}{$\mathrm{N}$} & $\mathrm{P}_{2} \mathrm{O}_{5}$ & \multirow{2}{*}{$\frac{\mathrm{K}_{2} \mathrm{O}}{\text { pre-sowing }}$} & \multirow[t]{2}{*}{$\mathrm{S}$} & \multirow{2}{*}{\multicolumn{2}{|c|}{ foliar }} \\
\hline & & pre-sowing & supplementary & & & & & \\
\hline \multirow[t]{4}{*}{1} & 2010 & 68 & 40 & 46 & 105 & & $\mathrm{~N}$ & $\mathrm{~S}$ \\
\hline & 2011 & 68 & 40 & 46 & 105 & & & \\
\hline & 2012 & 68 & 40 & 46 & 105 & & & \\
\hline & $\bar{x}$ & 68 & 40 & 46 & 105 & & & \\
\hline \multirow[t]{4}{*}{2} & 2010 & 79 & 40 & 5 & 68 & & & \\
\hline & 2011 & 84 & 40 & 16 & 68 & & & \\
\hline & 2012 & 61 & 40 & 0 & 97 & & & \\
\hline & $\bar{x}$ & 75 & 40 & 7 & 78 & & & \\
\hline \multirow[t]{3}{*}{3} & 2010 & & \multirow{3}{*}{\multicolumn{2}{|c|}{ same as for treatment No. 2}} & & 20 & & \\
\hline & 2011 & & & & & 15 & & \\
\hline & 2012 & & & & & 20 & & \\
\hline \multirow{5}{*}{4} & $\bar{x}$ & & & & & & & \\
\hline & 2010 & 79 & 60 & 5 & 68 & & & \\
\hline & 2011 & 84 & 20 & 16 & 68 & & & \\
\hline & 2012 & 61 & 40 & 0 & 97 & & & \\
\hline & $x$ & 75 & 40 & 7 & 78 & & & \\
\hline \multirow[t]{4}{*}{5} & 2010 & & & & & & 3.2 & 3.6 \\
\hline & 2011 & & same as for trea & No. 2 & & & 3.2 & 3.6 \\
\hline & 2012 & & & & & & 3.2 & 3.6 \\
\hline & $\bar{x}$ & & & & & & 3.2 & 3.6 \\
\hline \multirow[t]{4}{*}{6} & 2010 & & & & & & 3.2 & \\
\hline & 2011 & & same as for trea & No. 2 & & & 3.2 & \\
\hline & 2012 & & & & & & 3.2 & \\
\hline & $\bar{x}$ & & & & & & 3.2 & \\
\hline
\end{tabular}

replication of treatments Nos. 2-6 were put together and thus the composite samples for every replication were made. A day before harvest, plants were collected from $0.25 \mathrm{~m}^{2}$ area of every experimental plot. The total number of stems and the number productive stems of barley plants was counted; the number of grains per ear was calculated. During harvesting the grain yield collected from each experimental plot was weighed separately, the same day grain moisture content was determined and grain samples for determination of quality parameters were collected.

Soil $\mathrm{pH}$ was determined in $1 \mathrm{~N} \mathrm{KCl}$ extract using potentiometric method (ISO 10390:2005), plant available phosphorus, potassium, calcium and magnesium content - according to Egner-Riehm-Domingo (A-L) method, mineral nitrogen $\left(\mathrm{N}_{\text {min }}\right)$ and mineral sulphur $\left(\mathrm{S}_{\text {min }}\right)$ content - in $1 \mathrm{~N} \mathrm{KCl}$ extract (sample to solution ratio 1:2.5) using colorimetric method. Total nitrogen content in plants was determined using Kjeldahl method; the total nitrogen content multiplied by 6.25 gave the crude protein content. To determine the total sulphur content in plants the following procedure was used: the samples were dried at $60^{\circ} \mathrm{C}$ for 4 hours, then ground and combusted in a muffle furnace at $550^{\circ} \mathrm{C}$ for 8 hours; the ash then was dissolved in a mixture of nitric and hydrochloric acids and analysed for sulphur using the inductively coupled plasma (ICP) spectrometer "Optima 2100". Starch content was determined using a polarimeter. Spring barley grain yield was expressed in moisture of $14 \%$ and absolutely clean mass, straw yield - by the content of absolutely dry matter.

Statistical analyses of yield and biometric data were performed using the analysis of variance (ANOVA). Soil test data as well as the data on total nitrogen and total sulphur content in plants were presented as arithmetical means or medians with mean square deviations. Correlations were calculated between the plant nutrient content in soil and the plant productivity and quality indicators; probability levels $(* *-P>0.01, *-P>0.05)$ were determined.
Conditions of the experiment. Weather conditions. May 2010 was warm and rainy and the weather conditions were favourable for the germination and development of spring barley (Fig.). It was warm and very rainy in June - monthly rainfall amounted to $102.8 \mathrm{~mm}$ with $45.5 \mathrm{~mm}$ rainfall within the last ten days (this period was marked by heavy rains, the crops were lodged). July temperatures were unusually high, the mean daily temperatures for the first, second and last ten days of the month were by $3.1,6.6$ and $4.1{ }^{\circ} \mathrm{C}$ higher than the multiannual average. The rainfall in July was by $38 \%$ lower than usual, yet the soil was sufficiently moist. The lodged crops were attacked by fungal diseases. As the result of the extreme weather conditions the spring barley yield in 2010 was substantially lower than in other years of the experiment. The last days of April 2011 were warm, but in the beginning of May the air temperatures dropped, therefore the spring barley germination process was slowed down. The rest of May was warm; therefore the monthly mean of the daily temperature as well as the monthly rainfall was close to the multiannual average. Weather conditions favoured tiller development of barley plants. The first half of June was hot and dry. During the second ten days of June the weather conditions became normal. July and August were warm and very rainy, especially the last ten days of July; therefore the harvest took place later than in previous years of the experiment. Weather in May 2012 was unsettled. The mean daily temperatures were reaching $+18-21^{\circ} \mathrm{C}$ and then dropping suddenly to $+8-$ $9^{\circ} \mathrm{C}$. The period of spring night frosts lasted longer than usual. Rainfall was lower than usual, yet there were some heavy $(10.3-9.2 \mathrm{~mm})$ rains that resulted in formation of crust at soil surface. The germination and growth of spring barley were slow. The mean daily temperature for the first ten days of June was by $3^{\circ} \mathrm{C}$ lower than usual, cold nights slowed down the growth of barley plants even more. The second ten days of June were warmer; the temperature was close to the multiannual average. The total rainfall for June was $97.8 \mathrm{~mm}$, yet it was unevenly distributed: 

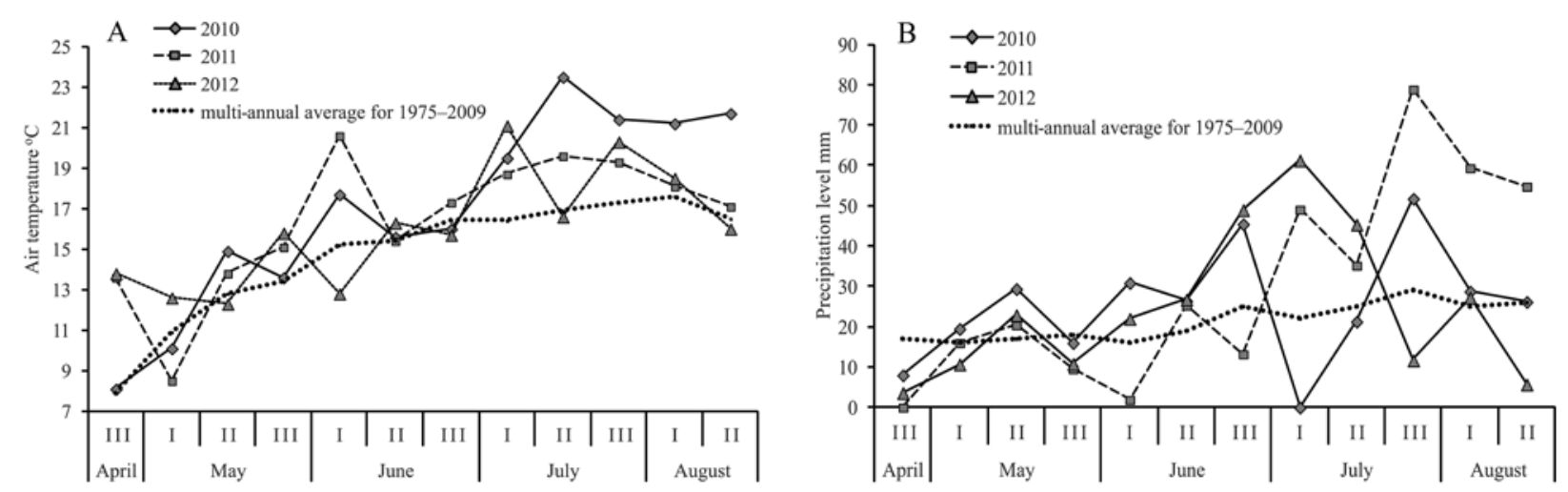

Figure. Means of the daily (24 hour) air temperature (A) and precipitation level (B) in 2010-2012 (Kybartai Weather Station)

11 June $-18.8 \mathrm{~mm}, 22$ June $-29.5 \mathrm{~mm}$. Heavy rains were accompanied by strong winds, but the crops were not lodged. July was warm and humid, favourable for the barley grain development as well as for fungal leaf spot diseases.

Soil. The experiment was conducted on a Bathihypogleyi-Calc(ar)ic Luvisol (LVk-gld-w). The following soil horizons were identified: Ap $-0-28 \mathrm{~cm}$, $\mathrm{AB}-29-40 \mathrm{~cm}, \mathrm{El}-40-51 \mathrm{~cm}, \mathrm{Bt}-51-57 \mathrm{~cm}, \mathrm{BC}-$ $57-122 \mathrm{~cm}, \mathrm{C}->122 \mathrm{~cm}$. Soil texture: Ap - silt loam, El - loam, BC - heavy clay. The top of the carbonate horizon and the gleyicity traces were determined at the $60 \mathrm{~cm}$ depth. Agrochemical properties of soil were determined every spring of the three years of this experiment; they are presented in Table 2. The $\mathrm{pH}$ value in the arable soil layer ranged from 6.5 to 6.9, plant-available phosphorus $\left(\mathrm{P}_{2} \mathrm{O}_{5}\right)$ level was very high, and plant-available potassium $\left(\mathrm{K}_{2} \mathrm{O}\right)$ level - high. The arable soil layer contained high levels of plant-available calcium (Ca) - 1821-3622 mg kg-1 and magnesium $(\mathrm{Mg})$ - 199-406 $\mathrm{mg} \mathrm{kg}^{-1}$ as well. Organic carbon $\left(\mathrm{C}_{\text {org }}\right)$ content in soil was average $-1.31-1.62 \%$. The type and agrochemical properties of the selected soil were suitable for spring barley growing. Mineral nitrogen levels in $0-60 \mathrm{~cm}$ soil layer, determined in spring, were low in 2010 and 2011, and average in 2012, while the levels of mineral sulphur were very low in 2010 and 2012, and average in 2011.

Table 2. Agrochemical properties of soil determined in spring before the pre-sowing fertilisation and sowing of spring barley

\begin{tabular}{|c|c|c|c|c|c|c|}
\hline \multirow[b]{3}{*}{ Properties } & \multicolumn{6}{|c|}{ Year } \\
\hline & \multicolumn{2}{|c|}{2010} & \multicolumn{2}{|c|}{2011} & \multicolumn{2}{|c|}{2012} \\
\hline & $\begin{array}{c}\text { value / } \\
\text { content* }\end{array}$ & $\begin{array}{c}\text { group of the } \\
\text { nutrient } \\
\text { content level** }\end{array}$ & $\begin{array}{l}\text { value / } \\
\text { content }\end{array}$ & $\begin{array}{l}\text { group of the } \\
\text { nutrient } \\
\text { content level }\end{array}$ & $\begin{array}{l}\text { value / } \\
\text { content }\end{array}$ & $\begin{array}{c}\text { group of } \\
\text { the nutrient } \\
\text { content level }\end{array}$ \\
\hline $\mathrm{pH}_{\mathrm{KCl}}$ & $6.5 \pm 0.17$ & - & $6.6 \pm 0.31$ & - & $6.9 \pm 0.15$ & - \\
\hline plant-available $\mathrm{P}_{2} \mathrm{O}_{5} \mathrm{mg} \mathrm{kg}^{-1}$ & $323 \pm 18.8$ & 5 & $232 \pm 46.7$ & 5 & $287 \pm 73.4$ & 5 \\
\hline plant-available $\mathrm{K}_{2} \mathrm{O} \mathrm{mg} \mathrm{kg}^{-1}$ & $204 \pm 11.5$ & 4 & $178 \pm 17.1$ & 4 & $222 \pm 64.2$ & 5 \\
\hline $\mathrm{N}_{\min 0-30 \mathrm{~cm}} \mathrm{~kg} \mathrm{ha}^{-1}$ & $25.6 \pm 2.20$ & - & $22.0 \pm 2.37$ & - & $39.8 \pm 8.57$ & - \\
\hline $30-60 \mathrm{~cm} \mathrm{~kg} \mathrm{ha}^{-1}$ & $18.1 \pm 0.59$ & - & $17.7 \pm 1.50$ & - & $43.6 \pm 15.69$ & - \\
\hline $0-60 \mathrm{~cm} \mathrm{~kg} \mathrm{ha}^{-1}$ & $43.7 \pm 2.79$ & 2 & $39.7 \pm 3.87$ & 2 & $83.4 \pm 24.26$ & 3 \\
\hline $\mathrm{S}_{\min 0-30 \mathrm{~cm}} \mathrm{~kg} \mathrm{ha}^{-1}$ & $5.0 \pm 1.20$ & - & $6.3 \pm 3.99$ & - & $2.3 \pm 1.16$ & - \\
\hline $30-60 \mathrm{~cm} \mathrm{~kg} \mathrm{ha}^{-1}$ & $4.3 \pm 1.42$ & - & $5.4 \pm 6.03$ & - & $2.5 \pm 1.18$ & - \\
\hline $0-60 \mathrm{~cm} \mathrm{~kg} \mathrm{ha}^{-1}$ & $9.3 \pm 2.62$ & 1 & $11.7 \pm 10.02$ & 3 & $4.8 \pm 2.34$ & 1 \\
\hline
\end{tabular}

Note. * $-\mathrm{pH}, \mathrm{P}_{2} \mathrm{O}_{5}, \mathrm{~K}_{2} \mathrm{O}$ median and mean square deviation determined using 8 samples, $\mathrm{N}_{\min }, \mathrm{S}_{\min }-4$ samples; ** - groups of the nutrient content level: 1 - very low, 2 - low, 3 - average, 4 - high, 5 - very high.

\section{Results and discussion}

The observations of the changes in mineral nitrogen and mineral sulphur levels in soil and total nitrogen and total sulphur levels in plants were conducted in the experimental plots of treatments No. 2 and 3 at the end of spring barley tillering stage (BBCH 28). The presowing nitrogen fertilisation rates were the same for both treatments: $79 \mathrm{~kg} \mathrm{ha}^{-1}$ in $2010,84 \mathrm{~kg} \mathrm{ha}^{-1}$ in 2011 and 61 $\mathrm{kg} \mathrm{ha}^{-1}$ in 2012, while pre-sowing sulphur fertilisers were applied only in the plots of treatment No. $3: 20 \mathrm{~kg} \mathrm{ha}^{-1}$ in 2010, $15 \mathrm{~kg} \mathrm{ha}^{-1}$ in 2011 and $20 \mathrm{~kg} \mathrm{ha}^{-1}$ in 2012.

Mineral nitrogen content in $0-60 \mathrm{~cm}$ soil layer and total nitrogen content in plants in 2010 were lower compared to those of the other experimental years due to the lower temperatures in the first half of May, when spring barley plants were at tillering stage (Tables 3-4).
In 2011 and 2012, the levels of mineral nitrogen in soil ranged from 148 to $179 \mathrm{~kg} \mathrm{ha}^{-1}$. According to the nitrogen sufficiency estimation scale, the desirable level of mineral nitrogen in $0-60 \mathrm{~cm}$ soil layer at this period of the growing season is $120 \mathrm{~kg} \mathrm{ha}^{-1}$, thus the aforementioned mineral nitrogen levels should be considered as very high and sufficient for the growth of barley plants (Staugaitis et al., 2009).

Significant differences were revealed between the mineral sulphur levels in $0-60 \mathrm{~cm}$ layer of soil at the end of spring barley tillering stage $(\mathrm{BBCH} 28)$ determined in different years of the experiment: in $2010-8.5 \mathrm{~kg} \mathrm{ha}^{-1}$ in sulphur-untreated plots and $9.5 \mathrm{~kg}$ $\mathrm{ha}^{-1}$ in plots treated with sulphur at $\mathrm{S}_{20}$ rate, in 2011 23.7 and $42.3 \mathrm{~kg} \mathrm{ha}^{-1}$, respectively, in $2012-126.8$ and $144.1 \mathrm{~kg} \mathrm{ha}^{-1}$, respectively. Since the obtained data on the total sulphur content in plants revealed quite a different 
Table 3. Mineral nitrogen $\left(\mathrm{N}_{\min }\right)$ and mineral sulphur $\left(\mathrm{S}_{\min }\right)$ levels in soil before the supplementary fertilisation at the end of spring barley tillering stage (BBCH 28)

\begin{tabular}{ccccccc}
\hline \multirow{2}{*}{$\begin{array}{c}\text { Soil layer } \\
\mathrm{cm}\end{array}$} & \multicolumn{7}{c}{2010} & \multicolumn{5}{c}{ Treatment No. } & 2012 \\
\cline { 2 - 7 } & 2 & 3 & 2 & 3 & 3 \\
\hline \multicolumn{7}{c}{$\mathrm{N}_{\min } \mathrm{kg} \mathrm{ha}^{-1}$} \\
$0-30$ & $94.3 \pm 3.75$ & $73.1 \pm 18.38$ & $112.5 \pm 5.30$ & $97.0 \pm 39.32$ & $113.6 \pm 7.28$ & $115.6 \pm 24.82$ \\
$30-60$ & $29.5 \pm 5.30$ & $29.8 \pm 6.01$ & $66.9 \pm 32.60$ & $50.6 \pm 12.45$ & $49.0 \pm 9.69$ & $44.9 \pm 8.63$ \\
$0-60$ & $123.8 \pm 9.05$ & $102.9 \pm 24.39$ & $179.4 \pm 37.90$ & $147.6 \pm 51.77$ & $162.6 \pm 16.97$ & $160.5 \pm 33.45$ \\
\hline \multicolumn{7}{c}{$\mathrm{S}_{\min } \mathrm{kg} \mathrm{ha}^{-1}$} \\
$0-30$ & $2.7 \pm 1.27$ & $3.4 \pm 0.99$ & $16.0 \pm 11.74$ & $31.0 \pm 10.96$ & $65.3 \pm 11.39$ & $76.1 \pm 18.86$ \\
$30-60$ & $5.8 \pm 0.14$ & $6.1 \pm 0.21$ & $7.7 \pm 1.27$ & $11.3 \pm 1.27$ & $61.5 \pm 12.31$ & $68.0 \pm 7.86$ \\
$0-60$ & $8.5 \pm 1.41$ & $9.5 \pm 1.20$ & $23.7 \pm 13.01$ & $42.3 \pm 12.23$ & $126.8 \pm 23.70$ & $144.1 \pm 26.72$ \\
\hline
\end{tabular}

Note. All data are expressed as arithmetic means and mean square deviations.

picture (Table 4), it is likely that the method chosen for determining the mineral sulphur content in soil was not the right one. Some researchers (Willms, 2005) indicated another probable explanation: it is possible that in 2012 the levels of mineral sulphur in soil rose due to the high temperatures in the fifteen days of April and first fifteen days of May - sulphates could rise from the deeper soil layers.

Table 4. Total nitrogen (N) and total sulphur (S) levels in spring barley leaves at tillering stage (BBCH 28) before supplementary fertilisation, $\%$ of absolutely dry matter (mean for treatments No. 2, 4, 5 and 6)

\begin{tabular}{cccc}
\hline Elements & 2010 & 2011 & 2012 \\
\hline $\mathrm{N}$ & $5.36 \pm 0.12$ & $6.53 \pm 0.22$ & $5.79 \pm 0.08$ \\
$\mathrm{~S}$ & $0.39 \pm 0.04$ & $0.31 \pm 0.02$ & $0.24 \pm 0.02$ \\
$\mathrm{~N}: \mathrm{S}$ & 13.7 & 21.1 & 24.1 \\
\hline
\end{tabular}

Note. All data (with exception of N:S ratio) are expressed as arithmetic means and mean square deviations.

The available scientific evidence indicates that the optimal level of total nitrogen in spring barley leaves at tillering stage (BBCH 28$)$ is 3.5-6.4\%, and total sulphur $->0.3 \%$ (Breuer et al., 2003; Olfs et al., 2012). The results obtained from our research revealed that the levels of total nitrogen in spring barley leaves at tillering stage (BBCH 28) were always optimal, while the levels of total sulphur were optimal in 2010 , close to the bottom line of the optimal level in 2011 and below that line in 2012. The N:S ratio in plant leaves indicates the sulphur supply sufficiency; when the value of $\mathrm{N}: \mathrm{S}$ ratio in barley leaves is higher than 17, the supply of sulphur is insufficient (Zhao et al., 1996). In this way, sulphur deficiency was recorded in our experiment in 2011 and 2012.

Number of productive stems per unit of area indicates the productivity of grain crops. The numbers of spring barley productive stems in the plots of our field experiment ranged from 792 to 991 stems per $\mathrm{m}^{2}$ and depended mostly on the weather conditions (Table 5). The largest numbers of productive stems were developed in 2011 when cool and normally humid weather conditions in May favoured the tillering process. Different fertilisation schemes had no significant effect on the number of developed productive stems, except of the supplementary nitrogen fertilisation in 2011 - the plants treated with $\mathrm{N}_{20}$ rate developed fewer numbers of productive stems. Chlorophyll index was measured in the spring barley leaves at the end of barley heading stage (BBCH 55); according to the obtained results, it mostly depended on weather conditions (Table 5). Adjusted fertiliser rates had no significant effect on the chlorophyll index.

Table 5. Spring barley productivity indicators as affected by different fertilisation schemes

\begin{tabular}{|c|c|c|c|c|c|c|c|c|}
\hline \multirow[t]{2}{*}{$\begin{array}{l}\text { Treatment } \\
\text { No. }\end{array}$} & \multicolumn{4}{|c|}{$\begin{array}{l}\text { Number of productive stems } \\
\mathrm{m}^{-2}\end{array}$} & \multicolumn{4}{|c|}{$\begin{array}{c}\text { Chlorophyll index* } \\
\text { (determined using chlorophyll meter SPAD-502) }\end{array}$} \\
\hline & 2010 & 2011 & 2012 & $\bar{x}$ & 2010 & 2011 & 2012 & $\bar{x}$ \\
\hline 1 & 829 & 991 & 846 & 889 & 40.7 & 51.7 & 43.3 & 45.2 \\
\hline 2 & 797 & 967 & 850 & 870 & 40.7 & 52.1 & 43.4 & 45.4 \\
\hline 3 & 822 & 970 & 875 & 889 & 40.6 & 52.0 & 41.9 & 44.8 \\
\hline 4 & 846 & 933 & 876 & 885 & 42.5 & 52.1 & 42.1 & 45.6 \\
\hline 5 & 811 & 978 & 860 & 883 & 43.2 & 52.0 & 40.6 & 46.3 \\
\hline 6 & 792 & 961 & 832 & 862 & 42.6 & 50.3 & 42.8 & 45.2 \\
\hline $\mathrm{LSD}_{05}$ & 57.2 & 48.0 & 37.9 & 35.9 & 3.45 & 2.08 & 2.40 & 1.38 \\
\hline
\end{tabular}

* - determined after the supplementary fertilisation at BBCH 55: 1806 2010, 29062011 and 29062012

In 2011, the number of grains per ear was the lowest, while the number of productive stems was the highest (Table 6). High crop density results in deteriorated light conditions, thus the photosynthesis processes are slowed down. Statistical analysis confirmed the negative effect of the productive stem number on the number of grains per ear $(r=-0.443 * *)$. Three year averages reveal that different barley fertilisation schemes had no significant effect on the number of grains per ear, yet in certain cases an increase in the number of grains per ear was recorded when each year was evaluated individually: in 2010 this number increased when foliar nitrogen-sulphur fertilisation (ammonium sulphate) was applied (treatment No. 5), in 2011 - when pre-sowing sulphur fertilisation was applied (treatment No. 3), and in 2012 - when barley plants were treated foliarly with urea (treatment No. 6). Barley grains were the largest in 2011 due to the sufficient moisture and warmth during the grain-filling period, and the smallest - in 2010 when crops were lodged by heavy rains and winds in June (Table 6). In 2010, the supplementary nitrogen fertilisation resulted in a decrease of 1000 grain weight 
Table 6. 1000 grain weight as affected by different fertilisation schemes

\begin{tabular}{|c|c|c|c|c|c|c|c|c|}
\hline \multirow{2}{*}{$\begin{array}{c}\text { Treatment } \\
\text { No. }\end{array}$} & \multicolumn{4}{|c|}{ Number of grains per ear } & \multicolumn{4}{|c|}{1000 grain weight $g$} \\
\hline & 2010 & 2011 & 2012 & $\bar{x}$ & 2010 & 2011 & 2012 & $\bar{x}$ \\
\hline 1 & 19.2 & 17.8 & 22.4 & 19.8 & 36.5 & 49.1 & 39.9 & 41.8 \\
\hline 2 & 19.7 & 18.0 & 22.9 & 20.2 & 35.5 & 48.8 & 41.8 & 42.0 \\
\hline 3 & 19.0 & 18.9 & 22.8 & 20.2 & 36.0 & 49.2 & 40.8 & 42.0 \\
\hline 4 & 19.5 & 17.3 & 23.0 & 19.9 & 34.8 & 48.4 & 41.1 & 41.4 \\
\hline 5 & 20.4 & 17.1 & 22.6 & 20.0 & 38.3 & 49.9 & 39.8 & 42.7 \\
\hline 6 & 18.6 & 17.9 & 23.3 & 19.9 & 34.9 & 49.0 & 41.8 & 41.9 \\
\hline $\mathrm{LSD}_{05}$ & 1.14 & 0.72 & 0.66 & 0.48 & 0.97 & 0.93 & 1.42 & 0.85 \\
\hline
\end{tabular}

since more plants were lodged in the plots supplementary fertilised with nitrogen. Foliar treatment of plants with nitrogen-sulphur fertiliser ammonium sulphate resulted in the largest grains in 2010 and 2011.

Correlation calculations revealed a slightly negative effect of supplementary nitrogen fertilisation at the rate adjusted according to the nitrogen content in plant leaves on the 1000 grain weight $(r=-0.392 * *)$, while a moderate positive correlation $\left(r=0.474^{* *}\right)$ was found between the levels of mineral sulphur in soil determined before sowing and the 1000 grain weight.

The average grain yield in 2011 and 2012 was $4.5 \mathrm{t} \mathrm{ha}^{-1}$, and in $2010-2.72 \mathrm{t} \mathrm{ha}^{-1}$ (the crops were lodged). The yield of spring barley crop treated with $\mathrm{N}, \mathrm{P}_{2} \mathrm{O}_{5}$ and $\mathrm{K}_{2} \mathrm{O}$ rates calculated for achieving the $5 \mathrm{t} \mathrm{ha}^{-1}$ grain yield and adjusted according to the results of regular soil tests conducted in spring (treatment No. 2) was close to the yield of spring barley crop treated with $\mathrm{N}, \mathrm{P}_{2} \mathrm{O}_{5}$ and $\mathrm{K}_{2} \mathrm{O}$ rates calculated for achieving the $5 \mathrm{t} \mathrm{ha}^{-1}$ grain yield (treatment No. 1) in all years of the experiment; the differences did not exceed the $\mathrm{LSD}_{05}$ value. Spring treatment of plants with sulphur fertiliser rate adjusted to the mineral sulphur content in $0-60 \mathrm{~cm}$ soil layer determined in spring (treatment No. 3) resulted in a grain yield increase: in $2010-23.0 \%\left(\mathrm{~S}_{20}\right.$ rate $)$, in $2011-5.1 \%\left(\mathrm{~S}_{15}\right.$ rate $)$, in 2012 $-9.0 \%\left(\mathrm{~S}_{20}\right.$ rate $)$; an average yield increase for the three years of the experiment $-11.2 \%$. Treatment of plants with supplementary nitrogen fertiliser rate adjusted according to the results of analyses of nitrogen content in plant leaves at the tillering (BBCH 28) stage (treatment No. 4) did not increase the grain yield.
Foliar fertilisation of spring barley resulted in a statistically significant grain yield increase only in 2010, when mineral sulphur and mineral nitrogen content $(8.5$ and $123 \mathrm{~kg} \mathrm{ha}^{-1}$, respectively) in $0-60 \mathrm{~cm}$ soil layer at spring barley tillering stage (BBCH 28) was significantly lower in comparison to the other experimental years. The obtained yield increase was $41.8 \%$ when ammonium sulphate had been applied and $12.1 \%$ when urea had been applied. Thus the pre-sowing as well as foliar applications of sulphur fertilisers were the most effective ones from the grain yield point of view.

Differences between the spring barley straw yield increases obtained using different fertilisation schemes were statistically insignificant at the $\mathrm{LSD}_{05}$ level when the results of every experimental year were evaluated separately; yet the means calculated for 2010 2012 period revealed that spring treatment of plants with sulphur fertiliser (treatment No. 3) and foliar application of nitrogen-sulphur fertiliser ammonium sulphate at $15 \mathrm{~kg}$ $\mathrm{ha}^{-1}$ rate (treatment No. 5) resulted in an $11 \%$ straw yield increase; taking each experimental year separately, this increase was as follows: $19.4 \%$ in $2010,9.8 \%$ in 2011 , and $8.3 \%$ in 2012 (Table 7). Thus the application of sulphur fertilisers was the most effective one from the straw yield point of view as well. Several researchers indicate that sulphur fertilisation increases the winter wheat grain and straw yield (Zhao et al., 1996), yet the effect of sulphur fertilisation depends strongly on the conditions profiling the particular year (Kulhanek et al., 2014).

The two-year means of starch content in spring barley grains as affected by the different fertilisation

Table 7. Spring barley grain and straw yields as affected by different fertilisation schemes

\begin{tabular}{|c|c|c|c|c|c|c|c|c|c|}
\hline \multirow{2}{*}{$\begin{array}{c}\text { Treatment } \\
\text { No. }\end{array}$} & \multicolumn{5}{|c|}{ Grain yield t ha ${ }^{-1}$} & \multicolumn{4}{|c|}{ Straw yield t ha ${ }^{-1}$} \\
\hline & 2010 & 2011 & 2012 & $\bar{x}$ & $\begin{array}{c}\text { increase } \\
\%\end{array}$ & 2010 & 2011 & 2012 & $\bar{x}$ \\
\hline 1 & 2.61 & 4.48 & 4.39 & 3.82 & - & 1.47 & 2.22 & 2.63 & 2.10 \\
\hline 2 & 2.39 & 4.47 & 4.35 & 3.74 & 100 & 1.24 & 2.05 & 3.02 & 2.10 \\
\hline 3 & 2.94 & 4.70 & 4.86 & 4.16 & 111.2 & 1.48 & 2.25 & 3.27 & 2.33 \\
\hline 4 & 2.64 & 4.33 & 4.34 & 3.77 & 100.8 & 1.46 & 2.28 & 3.04 & 2.26 \\
\hline 5 & 3.05 & 4.62 & 4.65 & 4.11 & 109.9 & 1.74 & 2.09 & 3.13 & 2.32 \\
\hline 6 & 2.68 & 4.48 & 4.52 & 3.93 & 105.1 & 1.44 & 2.07 & 2.79 & 2.10 \\
\hline $\mathrm{LSD}_{05}$ & 0.247 & 0.282 & 0.248 & 0.183 & & 0.584 & 0.589 & 0.419 & 0.219 \\
\hline
\end{tabular}

schemes were calculated; the obtained differences were statistically insignificant at the $\mathrm{LSD}_{05}$ level (Table 8). In 2011, the content of starch in grains was lower than in 2012, yet in 2011 there was a noticeable grain starch content increase in two cases: when the plants had been treated with supplementary nitrogen fertiliser rate adjusted according to the results of analyses of nitrogen content in plant leaves at the tillering stage (BBCH 28) - that year the aforementioned rate was decreased from 40 to $20 \mathrm{~kg} \mathrm{ha}^{-1}$; and when the plants had been treated with foliar sulphur (ammonium sulphate) fertiliser rate adjusted according to the results of analyses of sulphur content in plant leaves at the tillering stage (BBCH 28). In both cases the grain starch content levels were close to those found in 2012.

During the three years of our experiment the content of crude protein in spring barley grains (absolutely dry matter) ranged from $11.03 \%$ to $13.06 \%$ (Table 8 ), yet the obtained quantitative differences between the treatments were statistically insignificant at the $\mathrm{LSD}_{05}$ level. It could be noticed though, that the content of crude protein in grains was lower when spring barley plants had 
Table 8. Content of starch and crude protein in spring barley grains as affected by different fertilisation schemes (\%) of absolutely dry matter

\begin{tabular}{|c|c|c|c|c|c|c|c|}
\hline \multirow{2}{*}{$\begin{array}{c}\text { Treatment } \\
\text { No. }\end{array}$} & \multicolumn{3}{|c|}{ Starch } & \multicolumn{4}{|c|}{ Crude protein } \\
\hline & 2011 & 2012 & $\bar{x}$ & 2010 & 2011 & 2012 & $\bar{x}$ \\
\hline 1 & 59.2 & 63.6 & 61.4 & 11.34 & 12.31 & 11.38 & 11.68 \\
\hline 2 & 58.3 & 65.6 & 61.9 & 11.88 & 12.59 & 11.94 & 12.14 \\
\hline 3 & 58.5 & 63.1 & 60.8 & 11.03 & 12.41 & 12.25 & 11.90 \\
\hline 4 & 62.9 & 63.6 & 63.2 & 11.34 & 12.72 & 12.16 & 12.07 \\
\hline 5 & 62.4 & 64.1 & 63.2 & 12.19 & 12.66 & 13.06 & 12.64 \\
\hline 6 & 57.2 & 63.4 & 60.3 & 11.72 & 12.69 & 11.97 & 12.13 \\
\hline $\mathrm{LSD}_{05}$ & 2.42 & 4.48 & 2.63 & 1.321 & 0.781 & 1.427 & 0.820 \\
\hline
\end{tabular}

been treated with fertiliser rates calculated for achieving the $5 \mathrm{t} \mathrm{ha}^{-1}$ grain yield (higher phosphorus and potassium rates, somewhat lower nitrogen rate).

\section{Conclusions}

After having analysed the results obtained from our experiment where different spring barley (Hordeum vulgare L.) fertilisation schemes were compared, the following conclusions can be drawn:

1. The average quantitative differences between the fertiliser rates calculated for achieving the $5 \mathrm{t} \mathrm{ha}^{-1}$ spring barley grain yield and adjusted according to the results of regular soil tests conducted in spring: content of phosphorus $\left(\mathrm{P}_{2} \mathrm{O}_{5}\right)$ and potassium $\left(\mathrm{K}_{2} \mathrm{O}\right)$ in $0-20 \mathrm{~cm}$ soil layer, determined using A-L method, content of mineral nitrogen $\left(\mathrm{N}_{\min }\right)$ in $0-60 \mathrm{~cm}$ soil layer, determined using colorimetric method, and the not adjusted rates depended on the nutrient: nitrogen fertiliser rate was by $6.5 \%$ higher, while the rates of phosphorus and potassium - by $15 \%$ and $74 \%$ lower, respectively. On the other hand, the obtained grain yield differences between the aforementioned treatments did not exceed the $\mathrm{LSD}_{05}$ value.

2. The mineral sulphur $\left(\mathrm{S}_{\min }^{05}\right)$ content determined in $0-60 \mathrm{~cm}$ soil layer in spring was very low in 2010 and 2012 and average in 2011; the treatment of spring barley crop with $\mathrm{S}_{15-20}$ rates the grain yield increased by $5.1-23 \%$, straw yield - by $8.3-19.4 \%$.

3. $\mathrm{N}_{\min }$ levels in 0-60 $\mathrm{cm}$ soil layer, determined at the end of spring barley tillering stage (BBCH 28), were high and very high (102-173 $\left.\mathrm{kg} \mathrm{ha}^{-1}\right)$; at the same time the content of total nitrogen in barley leaves was optimal. Due to this, the adjustment of supplementary fertilisation (increasing/decreasing of the nitrogen rate by $20-60 \mathrm{~kg} \mathrm{ha}^{-1}$ ) had no significant effect on the crop yield, productivity components and starch and crude protein content in grains.

4. Foliar fertilisation of spring barley plants increased the grain yield statistically significantly only in 2010 when mineral sulphur and mineral nitrogen content in $0-60 \mathrm{~cm}$ soil layer at spring barley tillering stage (BBCH 28) was significantly lower $(8.5 \pm 1.13$ and 123 $\pm 9.1 \mathrm{~kg} \mathrm{ha}^{-1}$, respectively). The obtained yield increase was $41.8 \%$ when ammonium sulphate had been applied and $12.1 \%$ when urea had been applied.

5. Different fertilisation schemes had no significant effect on the number of productive stems, number of grains per ear, chlorophyll index in the spring barley leaves at the end of heading stage (BBCH 55), and the content of starch and crude protein in barley grains. Foliar treatment of plants with nitrogen-sulphur fertiliser ammonium sulphate resulted in an increase in 1000 grain weight.

\section{References}

Aulakh M. S., Malhi S. S. 2004. Fertilizer nitrogen use efficiency as influenced by interactions with other nutrients. Moisier A. et al. (eds.). Agriculture and the nitrogen cycle, p. 181-191

Blake-Kalff M. M. A., Hawkesford M. J., Zhao F. J., McGrath S. P. 2000. Diagnosing sulfur deficiency in field-grown oilseed rape (Brassica napus L.) and wheat (Triticum aestivum L.). Plant and Soil, 225: 95-107 http://dx.doi.org/10.1023/A:1026503812267

Blum S. Ch., Lehmann J., Solomon D., Caires E. F., Alleoni L. R. F. 2013. Sulfur forms in organic substrates affecting S mineralization in soil. Geoderma, 200-201: $156-164$ http://dx.doi.org/10.1016/j.geoderma.2013.02.003

Breuer J., König V., Merkel D., Olfs H. W., Steingrobe B., Stimpfl E., Wissemeier A. H., Zorn W. 2003. Die Pflanzenanalyse zur Diagnose des Ernährungszustandes von Kulturpflanzen. Agrimedia, p. 33-34 (in German)

Ercoli L., Arduini I., Mariotti M., Lulli L., Masoni A. 2012. Management of sulphur fertiliser to improve durum wheat production and minimise $\mathrm{S}$ leaching. European Journal of Agronomy, 38: 74-82

http://dx.doi.org/10.1016/j.eja.2011.12.004

Ergebnisse der $\mathrm{N}_{\min } / \mathrm{S}_{\min }$-Untersuchungen auf den Testflächen-Winterungen. 2005. Landwirtschaftliche Fachbehörde. <http://www.lms-beratung.de/ upload/59/1137490874_14754_16600.pdf $>$ [accessed 16 07 2014] (in German)

Jamal A., Moon Y. S., Abdid M. Z. 2010. Sulphur - a general overview and interaction with nitrogen. Australian Journal of Crop Science, 4 (7): 523-529

Järvan M., Edesi L., Adamson A., Lukme L., Akk A. 2008. The effect of sulphur fertilization on yield, quality of protein and baking properties of winter wheat. Agronomy Research, 6 (2): 459-469

Kanal A., Kautz T., Ellmer F., Rühlmann J. 2003. Effects of long-term organic and mineral fertilization on sulphur and nitrogen supply of spring barley in Berlin-Dahlem (Germany) and Tartu (Estonia). Archives Agronomy and Soil Science, 49: 543-554 (in German) http://dx.doi.org/10.1080/03650340310001594808

Kulczycki G. 2011. The effect of soil and foliar sulphur application on winter wheat yield and soil properties. Fertilizers and Fertilization, 43: 21-28

Kulhanek M., Balik J., Černy J., Peklova L., Sedlar O. 2014. Winter wheat fertilizing using nitrogen-sulphur fertilizer. Archives of Agronomy and Soil Science, 60 (1): 67-74 http://dx.doi.org/10.1080/03650340.2013.771260

Messick D. L., Fan M. X., de Brey C. 2005. Global sulphur requirement and sulphur fertilizers. Landbauforschung Völkenrode, 283 (spec. iss.): 97-104

Olfs H. W., Fuchs M., Ortseifen U., Schintling-Horny L., von Chappuis A., Zerulla W., Erdle K. 2012. SchwefelDüngung effizient gestalten. Fachzentrum Land- und Ernährungswirtschaft. DLG-Merkblatt 373: 4-26 (in German) 
Schnug E., Haneklaus S. 1998. Diagnosis of sulphur nutrition. Schung E. (ed.). Sulfur in agroecosystems, p. 1-36

Schnug E., Haneklaus S. 2005. The role of sulphur in sustainable agriculture. Landbauforschung Völkenrode, 283 (spec. iss.): $131-135$

Schwefelversorgung von Kulturpflanzen - Bedarfsprognose und Düngung. 2000. Standpunkt des VDLUFA (Verband Deutscher Landwirtschaftlicher Untersuchungs- und Forschungsanstalten), 8 p. (in German)

Skwierawska M., Zawartka L., Zawadzki B. 2008. The effect of different rates and forms of applied sulphur on nutrient composition of planted crops. Plant, Soil and Environment, 54 (5): $179-189$

Staugaitis G., Pečkytė A. 2008. Effect of mineral fertilisers with different composition on yield, grain size parameters and quality of malting barley. Vagos, 80 (33): 108-116

Staugaitis G., Mažvila J., Vaišvila Z., Arbačiauskas J., Putelis L., Adomaitis T. 2009. Soil mineral nitrogen testing in Lithuania. Fertilizers and Fertilization, 37: 99-107

Šlepetienė A., Šlepetys J., Kavoliutė F., Liaudanskienė I., Kadžiulienė Ž. 2007. Changes in carbon, nitrogen, phosphorus and sulphur in West Samogitia natural and different agrarian land-use systems. ZemdirbysteAgriculture, 94 (3): 90-99 (in Lithuanian)
Wiesler F., Armbruster M. 2009. The application of the $\mathrm{N}_{\text {min }}$ soil test as an element of integrated nitrogen management strategies in agriculture. Fertilizers and Fertilization, 37: $50-58$

Willms M. 2005. Landwirtschaftliche Ursachen hoher Sulfatgehalte in gefördertem Trinkwasser: Dissertation zur Erlangung des Doktorgrades der Fakultät für Agrarwissenschaften der Georg-August-Universität Göttingen (in German)

Zhao F. J., Hawkesford M. J., Warrilow A. G. S., McGrath S. P., Clarkson D. T. 1996. Responses of two wheat varieties to sulphur addition and diagnosis of sulphur deficiency. Plant and Soil, 181 (2): 317-327 http://dx.doi.org/10.1007/BF00012066

Zhao K. J., McGrath S. P., Blake-Kalff M. M. A., Link A., Tucker M. 2003. Crop responses to sulphur fertilisation in Europe. Proceedings of the International Fertiliser Society, 504: 26-51

Zhao F. J., Fortune S., Barbosa V. L., McGrath S. P., Stobart R., Bilsborrow P. E., Booth E. J., Brown A., Robson P. 2006. Effects of sulphur on yield and malting quality of barley. Journal of Cereal Science, 43 (3): 369-377 http://dx.doi.org/10.1016/j.jcs.2005.12.003

ISSN 1392-3196 / e-ISSN 2335-8947

Zemdirbyste-Agriculture, vol. 101, No. 4 (2014), p. 373-380

DOI $10.13080 / \mathrm{z}-\mathrm{a} .2014 .101 .047$

\title{
Ivairiais diagnostikos metodais apskaičiuotų azoto ir sieros trąšų normų įtaka vasariniams miežiams
}

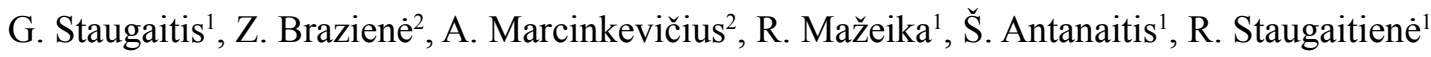

${ }^{1}$ Lietuvos agrarinių ir miškų mokslų centro Agrocheminių tyrimų laboratorija

${ }^{2}$ Lietuvos agrarinių ir miškų mokslų centro Rumokų bandymų stotis

\section{Santrauka}

Siekiant nustatyti azoto ir sieros trąšu normu įtaką vasariniams miežiams, 2010-2012 m. Lietuvos agrariniu ir miškų mokslų centro Rumokų bandymų stotyje atlikti tyrimai. Bandymai vykdyti derlingame paprastajame giliau glëjiškame karbonatingame išplautžemyje (IDk-g0), kuriame vyrauja dulkinis vidutinio sunkumo priemolis ant molio. Prieš sejją dirvožemio $0-60 \mathrm{~cm}$ sluoksnyje nustatytas mineralinès sieros kiekis parodè, jog net dvejus metus dirvožemyje mineralinès sieros kiekis buvo labai mažas, o vienus metus - vidutinis, todèl tyrimų metais vasarinių miežių tręšimas sieros trąšomis $\left(\mathrm{S}_{15-20}\right)$ grūdų derlių padidino 5,1-23 \%, šiaudų - 8,3-19,4 \%.

Tyrimų metais vasarinių miežių krūmijimosi metu (BBCH 28 tarpsniu) dirvožemio 0-60 cm sluoksnyje nustatytas didelis ir labai didelis kiekis mineralinio azoto - $102-173 \mathrm{~kg} \mathrm{ha}^{-1}$, o augalų lapuose - optimalus kiekis suminio azoto. Dèl to papildomo tręšimo koregavimas azoto trąšu normą mažinant arba didinant nuo 20 iki $60 \mathrm{~kg} \mathrm{ha}^{-1}$ žymesnès ịtakos vasarinių miežių derliui, jo produktyvumo elementams ir grūduose esančiam krakmolo bei žalių baltymų kiekiui neturejo. Vasarinius miežius patręšus lapų trąšomis, esminis grūdų derliaus priedas gautas tik tais metais, kai BBCH 28 tarpsniu dirvožemio $0-60 \mathrm{~cm}$ sluoksnyje mineralinės sieros ir mineralinio azoto buvo gerokai mažiau nei kitais tyrimų metais - atitinkamai 8,5 ir $123 \mathrm{~kg} \mathrm{ha}^{-1}$. Patręšus amonio sulfatu gautas 41,8 \%, karbamidu $-12,1 \%$ derliaus priedas.

Reikšminiai žodžiai: azoto ir sieros trąšos, dirvožemio tyrimai, lapų tyrimai, vasariniai miežiai. 